\title{
An exceptionally preserved conulariid from Ordovician erratics of Northern European Lowlands
}

\author{
Consuelo Sendino $^{1}$ ([) $\cdot$ Martin M. Bochmann ${ }^{2}$
}

Received: 1 July 2020 / Accepted: 17 November 2020 / Published online: 16 January 2021

(C) The Author(s) 2021

\begin{abstract}
A conulariid preserved in three dimensions from Ordovician fluvioglacial erratics of the Northern European Lowlands (North German Plain) is described under open nomenclature. It is assigned to the genus Conularia with similarities to Baltoscandian conulariids. The lithology of the erratic boulder and fauna contained in it provide important information on the origin and transport direction of the sediment preserved in a kame from the Saalian glaciation. This paper deals with the site of origin of the boulder in Baltoscandia analysing the comprised palaeofauna, from a palaeostratigraphic and palaeogeographic point of view, from its deposition in Ordovician times until its arrival at its current location in the Late Pleistocene. It also reveals for the first time the internal structure of the conulariid aperture.
\end{abstract}

Keywords Ordovician · Baltoscandia $\cdot$ Glacial erratics $\cdot$ Northern european lowlands $\cdot$ Conularia $\cdot$ Conulariid aperture

\section{Introduction}

This article deals with a new conulariid form from an Ordovician erratic boulder collected in the Northern European Lowlands, NE Germany. There is only one specimen that is exceptionally preserved in three dimensions, keeping its aperture semi-closed. This allows seeing, for the first time, most of the internal part of the closure with rib continuation inwards.

Numerous well-preserved fossil invertebrates have been described and figured from Ordovician and Silurian erratics from Baltoscandia on the Baltica plate. Among these fossils are numerous macrofossils such as corals (Roemer 1885; Krause 1877; Stasińska 1967), graptolites (Walch 1771; Heidenhain 1869; Haupt 1878; Neben and Krueger 1973; Maletz and Schöning 2017), trilobites (Roemer 1885; Neben and Krueger 1971, 1973, 1979), cephalopods (von

Handling Editor: Mike Reich.

Consuelo Sendino

c.sendino-lara@nhm.ac.uk

Martin M. Bochmann

MartinM.Bochmann@web.de

1 Department of Earth Sciences, Natural History Museum, London SW7 5BD, UK

2 Dresden, Germany
Schlotheim 1820; Boll 1857; Roemer 1885; Neben and Krueger 1971, 1973; Dzik 1984; Kröger 2004), brachiopods (Roemer 1885; Krause 1877; Patrunky 1928; Neben and Krueger 1971, 1973, 1979), gastropods (Krause 1877; Roemer 1885; Patrunky 1928; Neben and Krueger 1971, 1973, 1979), bivalves (Neben and Krueger 1973), echinoderms (Krause 1877; Neben and Krueger 1971, 1979), hyoliths (Malinky 2007), bryozoans (Neben and Krueger 1973), sponges (Neben and Krueger 1979) and conulariids (Klöden 1834; Krause 1877; Roemer 1885; Holm 1893; Patrunky 1928; Schuijf 1960; Hucke and Voigt 1967; Neben and Krueger 1971, 1973, 1979; Hergarten 1988; Striegler 1992; Rudolph 1997; Schallreuter 1994; Bartholomäus and Böhmecke 2007) from palaeohabitats of relatively flat sea areas. They are presented in erratic boulders, or Geschiebe, the provenance of which may be fluvial as in the Pliocene of Sylt, Germany (von Hacht and von Hacht 1974; von Hacht 1985,1990 ) or glacial/glaciogenic in the Pleistocene of central Germany.

In the Pleistocene Nordic glacial area, the erratic boulders in the moraines from glaciofluvial deposits as well as periglacial formations have long been the object of scientific observation (Remelé 1883; Gottsche 1877; Jentzsch 1880; Noetling 1882; Hucke and Voigt 1967). The science of erratic boulders, which essentially originated in Germany, even encouraged geological investigations into the Scandinavian home centres. Indeed, there were times when 
the palaeontological knowledge of the sedimentary formations of Scandinavia learned through the fossil content of the erratic boulders was greater than that known from in situ strata (Lüttig 1991).

Baltic conulariids have been cited and described widely from Dalman (1824), Lindström (1867, 1882, 1884), Wiman (1905) and Holm (1893) to Brood (1979) and Jerre (1993, $1994 a, 1994 b)$ in taxonomic studies. New perspectives on their study have appeared including symbiotic interactions with other organisms such as bryozoans (Männil 1959; Vinn and Wilson 2015; Vinn et al. 2019). Some classical bibliographical references on conulariids from Baltica are those of Krause (1877), Wiman (1895), Bekker (1924), von Eichwald (1860), Leuchtenberg (1843) and Sandberger (1847). In other cases, there are citations about the presence of conulariids by strata, such as Bassler (1911). Studies on conulariids from erratics from the 1800 s were very common. Klöden (1834) was probably the first to cite conulariids from erratics, in this case from Brandenburg Province in what was Prussia. Boll (1859) cited two conulariid taxa from Mecklenburg. Barrande (1867) referred to an unpublished manuscript written by Boll the same year of his publication on three species, also from Mecklenburg, including two new conulariid species (Conularia cornucopiae and C. lima). Steusloff (1892) cited 'C.' orthoceratophila from Estonia. Neben and Krueger (1973, 1979) figured some conulariids from Kaolinsand erratics. Other researchers described conulariids from erratics and erected new species. Karsten (1869) described two species ( $C$. constricta von Eichwald and $C$. cf. marginata von Eichwald) from Orthoceras Limestone (Orthoceratitenkalk) erratics. Roemer (1876) illustrated and erected ' $C$.' orthoceratophila from erratics of Sorau, formerly in Brandenburg Province but now in Poland. Krause (1877) described for first time C. lanceolata from Beyrichia Limestone (Beyrichienkalk) erratics. In 1893, Holm described seven conulariid species from erratic boulders of
Sweden (C. scalaris, C. oelandica, C. bottnica, C. orthoceratophila Roemer, C. pulchella, C. cancellata Sandberger and $C$. pectinata), five of them being new species. Wiman described ' $C$ '. loculata from the Hemse Beds erratics in 1895; C. rhodinensis from Baltic Sea Limestone (Ostseekalk) boulders and $C$. holmii from Chasmops Limestone (Chasmopskalk) erratics in 1908. Delle (1937) described $C$. latviensis from Devonian erratics of Latvia. The list of references with conulariid erratics increased sporadically from the last quarter of the twentieth century to the present day, with amateur publications that have contributed the figuring of conulariids.

\section{Geologic setting, stratigraphy and palaeoenvironmental conditions}

\section{Pleistocene redeposition}

The glacial erratic boulder of our study was collected in an opencast mine pit in the Spree-Neisse district in southeast Brandenburg, where there is a mine complex formed by the Cottbus-Nord and Jänschwalde mines, about $157 \mathrm{~km}$ southeast of Berlin (Figs. 1, 2). The site is situated in the Baruth Ice-Marginal Valley (Baruther Urstromtal) that was created when the Scandinavian Ice Sheet covered the north of this valley (Ehlers et al. 2004). This ice-marginal valley is in the central part of the Northern European Lowland (NEL) that extends from the North Sea and the Baltic Sea to the foothills of the low mountain ranges of Central Europe and spreads from the Netherlands to Poland (Raab et al. 2016). The erratic boulder came from the east side of the Jänschwalde mine (coordinates: $51^{\circ} 46^{\prime} 51.4^{\prime \prime} \mathrm{N}, 14^{\circ} 34^{\prime} 26.4^{\prime \prime}$ E) where there are Wartanian (Late Saalian) till remains on the surface. The mine area stretches from the Last Glacial

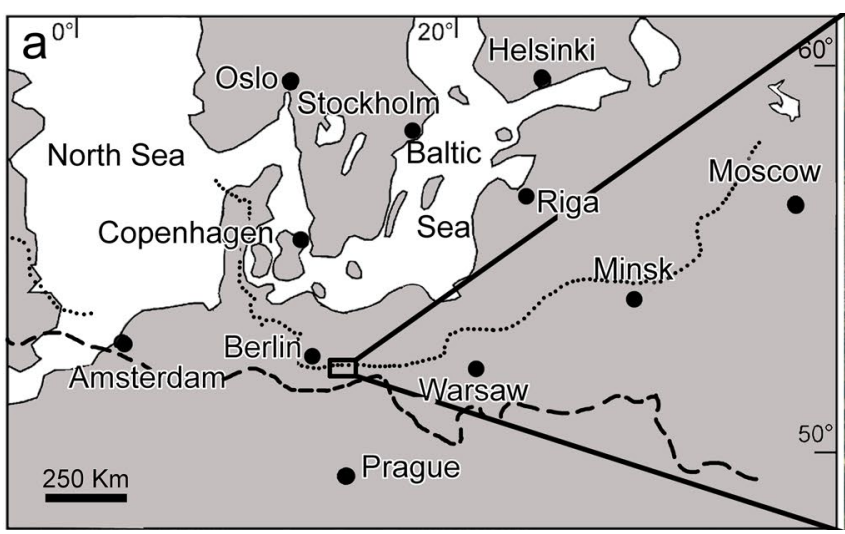

Fig. 1 Geographic location where the specimen was collected. a Location map of the site in Germany, striped and the dotted lines show the maximum extent of the Late Saalian and Late Weichse-

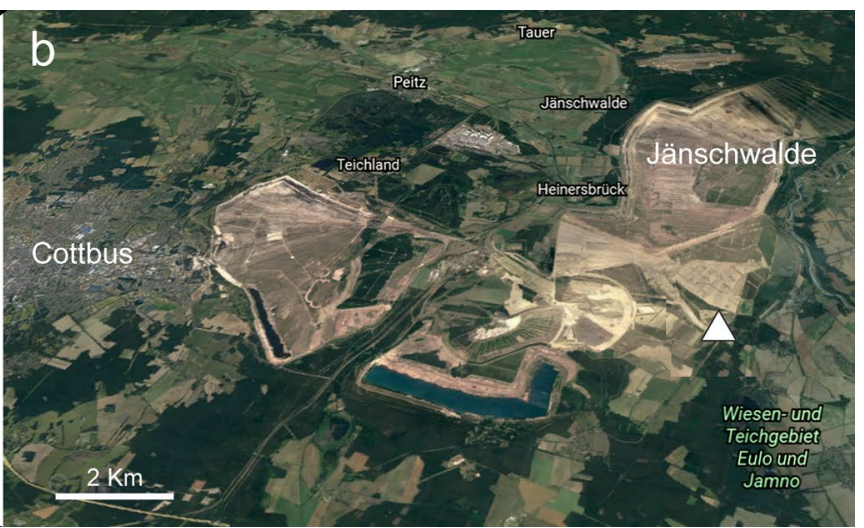

lian glaciations, respectively (location of the mine region after Hardt 2017). b Exact location for the erratic block (marked with a triangle) on a 3D Google Earth map 


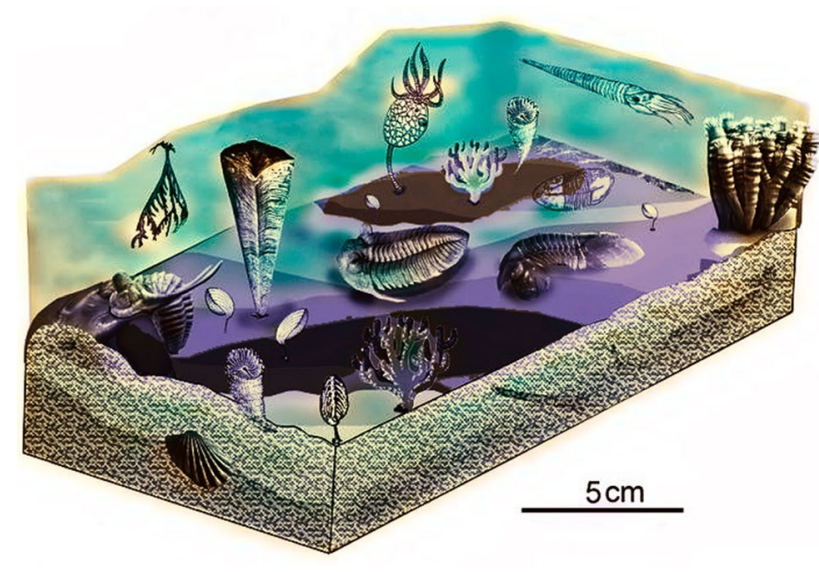

Fig. 2 Reconstruction of the Late Ordovician fauna found in the glacial erratic boulder from Brandenburg

Maximum ice sheet limit to the north and the maximum Wartanian ice sheet limit to the south (Fig. 1a).

The Baruth Ice-Marginal Valley was formed by the deposition of sediments from the meltwater and not the glacial movement itself (Haacke 2016). These sediments form diamict facies that contain mainly silt, sand and gravel. However, the sedimentary rocks that can be found as erratics are limestones and sandstones that differ from the surrounding sediments. The opencast mines of Cottbus-Nord and Jänschwalde contain numerous erratic boulders with Palaeozoic fauna suggesting sources in the Öland-Gotland region of Baltoscandia. The studied boulder could hardly have originated from redeposition of local sediments since no such compositions are found in the older units around the mine complex. Based on a computation model that predicts erratic dispersal according the nature of the substrate, Boulton et al. (1985) confirmed the empirical patterns of the ice stream with erratic fans in southern Sweden and Denmark derived from Öland and Åland. Erlingsson (1994) gave a further explanation on the dynamics of how the bottom between Öland and Gotland would have eroded because of a low ice shelf floating level. The fact that the studied limestone boulder is located at the maximum Wartanian ice sheet area, which is characterised by a low quantity of Palaeozoic limestone (Cepek et al. 1975; Hannemann and Schlegel 1965), implies the possibility of an older origin, from the Middle or Older Saalian, facies that came originally from a north-northeasterly direction (Böse 1990). But, it is at the beginning of the Wartanian Stage when the ice from the north-northeast moved fairly quickly to the regions south of Berlin. Therefore, this limestone boulder was derived from Baltoscandian rocks, dragged with the Scandinavian Ice Sheet towards the southern sector and most likely redeposited from the meltwater at the mine complex during the maximum Wartanian.

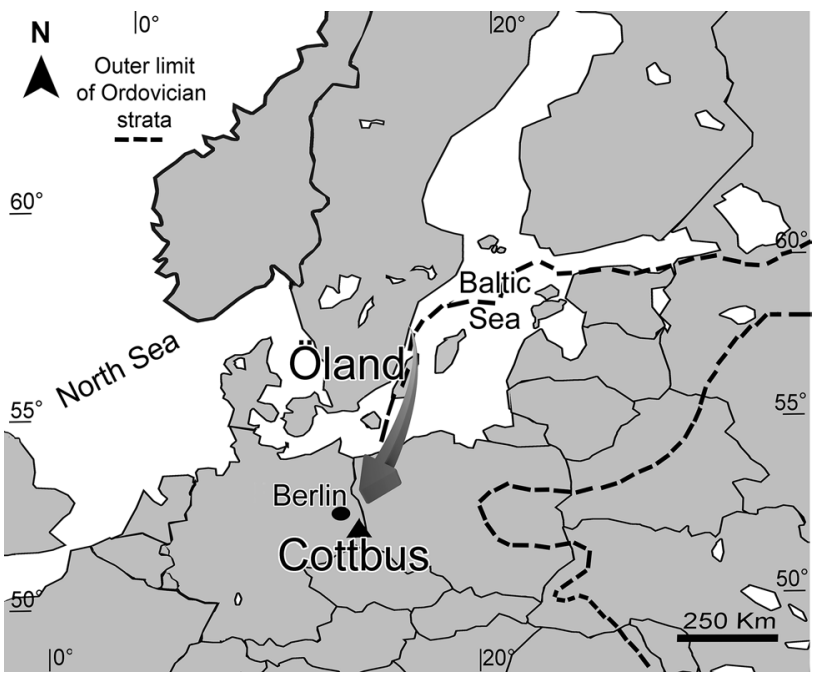

Fig. 3 Ice flow direction (arrow) from Öland to northeast Germany with erratic transport during the Wartanian and Weichselian (after Jaanusson 1982; Böse 1990; Böse and Górska 1995) and Ordovician epicontinental deposits in the Baltic region

Studying the palaeofauna present in the limestone boulder, with some Chasmops specimens, illaenids, orthids, graptolites, rugose corals and cephalopods from the Ordovician (Fig. 2) and a lithology with grey calcareous siltstones, points us to Baltic Ordovician strata that can be found from the south of the Gulf of Bothnia (Fig. 3, distribution of the Ordovician layers after Böse and Górska 1995) to northeastern Germany (Schulz 2003). Carbonate Ordovician strata are preserved and widely exposed in the northeast to southwest trending edge or southern slopes of the Baltic Shield (Stouge 2004). The exposures extend from the south to northeast of Öland and continue from northern Estonia into west Russia. Therefore, the closest Ordovician exposures to northeast Germany are located on the island of Öland.

\section{Late Ordovician origin}

Öland is a long $(150 \mathrm{~km}$.) and narrow (c. $20 \mathrm{~km}$.) Swedish island whose Cambro-Ordovician strata incline on the east in the Baltic Sea. This means the Cambrian strata are seen on the west coast of the island and the Ordovician only on the east coast (Hadding 1958). The youngest Ordovician is only exposed at the northernmost end of the island. The Ordovician limestone sections have provided numerous molluscs (Lindström 1884; Holm 1893), trilobites (Bohlin 1949), nautiloids (Dzik 1984), graptolites (Mierzejewski 2003) and many other taxonomic groups. Regarding conulariids, Barrande (1857) was one of the first to cite conulariids from the Ordovician of Öland in his comparative study with Bohemia, based on Angelin's personal comments. Lindström (1884) recorded the first appearance of conulariids 
in Sweden in the grey layers corresponding to the Upper Chasmops Limestone (Rollstein-Kalk after Remelé 1880 and Macrourus Limestone or Macroura-Kalk after Krause 1891), early Upper Ordovician, of Böda in Öland. We will use the term Macrourus Limestone instead of Rollstein Limestone, being the most used term in the literature on glacial erratic boulders.

Classic Ordovician unit names of Öland are the Dalby and Macrourus limestones, of Sandbian-Katian stages (Kukrusean-Oandu), a possible origin of the erratic boulder subject of our study. The Dalby Limestone unit (Jaanusson 1960) belongs to the highest beds (Kukrusean and Haljalan) exposed on Öland (Fig. 4), only known on the northern part of the island. There is a site on the island, Böda harbour (Böda Hamn), where abundant fossils preserved as internal moulds have been found. These include conulariids and other palaeofauna such as Chasmops and illaenids, that are also found as internal moulds in the erratic boulder found in the Brandenburg area. According the Jaanusson's (1960) observation, the non-glauconitic layers with internal moulds are more abundant closer to the surface. Bohlin (1949) pointed out that the higher beds of southern Öland become grey in their extension towards the north. Therefore, above the Dalby Limestone unit should be the Macrourus
Limestone, the current Freberga Formation of Sweden, that can only be found as erratics in the central part of Sweden and Öland (Martna 1955). This limestone contains abundant bryozoans in Dalarna, central Sweden, and they give their name to the formation (Bryozoan Limestone after Törnquist, 1883). But, bryozoans are not so evident on Öland island. The formation was characterized by Martna (1955) as containing small re-crystallised fossil fragments and the macropalaeofauna (Fig. 2) preserved as internal moulds, including rugose corals, brachiopods and trilobite molting remains. The arthropod fauna is the most visible, reaching almost $50 \%$ of the fauna present in the limestone. The irregular bending, the most fossiliferous one, characteristic of the Macrourus Limestone (Martna 1955), is also seen in part of the boulder, but the fossils studied occur in the regular bedded limestone including approximately $10 \%$ shell fragments. The fact that the Brandenburg boulder of our study coincides in lithology and palaeofauna with the Macrourus Limestone, suggests its origin in northern Öland, probably a nearby area now beneath the Baltic. Fossiliferous limestone boulders at the Cottbus-Nord and Jänschwalde complex were probably dragged by the ice flow in the Pleistocene and have been found almost $900 \mathrm{~km}$ to the south in the NEL.
Fig. 4 Upper Ordovician chart with correlation of the traditional and current regional terminology and the international standard (after Bergström 2007 and Wickström 2007)

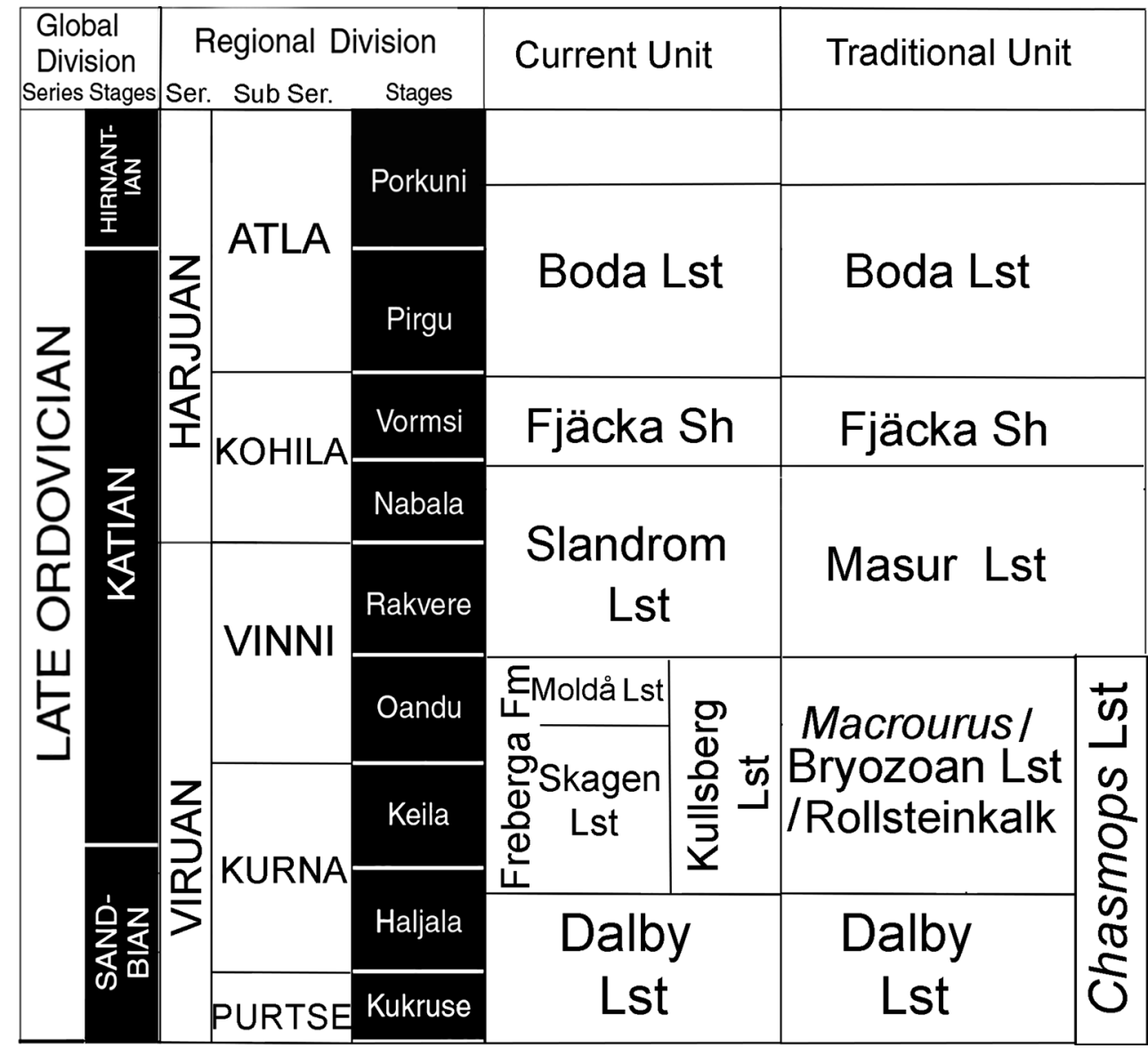


The first study of the Baltoscandian Macrourus Limestone was made by Sjögren (1852) on the island of Öland and their study continued with Andersson (1893), who was one of the first to explain that ice streams were able to transport Macrourus Limestone boulders from their original location to the south east of Öland. Other important works on Macrourus Limestone are those of Hadding (1958) and Martna (1955) and much later Schulz (2003) who published a synthesis of all erratics that can be found in north Germany. There are numerous works on erratics, and specifically of Macrourus Limestone, that exceed the scope this article; for references see Schulz (2003).

The Macrourus Limestone palaeofauna inhabited shallow pericontinental seas with an approximate latitude of $25^{\circ}-28^{\circ} \mathrm{S}$, close to the limit between temperate and tropical water faunal assemblages, and was associated with stormgenerated sedimentation. This is confirmed by the calcareous lithology (Bergström and Ahlberg 2004), abundant chasmopine trilobite fauna characteristic of shallow-water platform deposits (McNamara 1980), the conulariid with semi-closed aperture preserved (see discussion below) and the different orientation of the organisms inside the boulder. Fossils are distributed irregularly within the matrix. The analysed fauna, which could be classified as a necrocoenosis, was promptly buried and transported, most likely by a storm event that broke the trilobites and their moults by the tagmata boundaries. This is the beginning of the mud mounds and framework reefs that spread in the Late Ordovician of Baltoscandia (Kröger et al. 2017) and serve as a substrate to conulariids during their maximum biodiversity (Sendino 2009). On the eastern side of Öland are the oldest preserved mud mound structures (Flodén 1980), the conditions of which coincide with those of the fauna contained in the erratic boulder studied, and are probably of Katian age.

\section{Material and methods}

The material discussed herein has been collected by the second co-author (MMB) from glacial erratic boulders in the Spree-Neisse district in Brandenburg, northeast Germany (see Fig. 1 for precise location). These boulders contain fossils belonging to different groups (echinoderms, trilobites, brachiopods, cephalopods, and bryozoans) as internal moulds, with an exceptional preservation only seen in cases where they have been prepared. The conulariid of this article has been separated from a boulder of about $80 \times 40 \times 50$ $\mathrm{cm}^{3}$ and prepared, allowing us to describe fine details of its ornamentation and morphological elements.

This conulariid keeps a well-preserved test as internal mould. We will follow the terminology used by Mergl et al. (2016), with theca for the entire, organic and mineralized conulariid shell, periderm for the unpreserved external organic cover of the theca, and test for the mineralized part. This specimen is at the Natural History Museum (NHM), London.

Measurements of the specimen, description, and some of the biostratinomic processes experienced are given due to its uncommonly good preservation. As the tapering pyramidal shape is mostly consistent, we have calculated the ratio between test face width at the aperture to the test length. See morphological elements and some measurements used for the description in Fig. 5. Morphological and anatomical characters have been compared with coeval conulariids from Baltica.

Measurements taken. Apical angle-is the angle formed by the corners of each face; intercostal angle-is the angle formed by a pair of ribs at the midline; rib inclination-is the complementary angle of a rib with the corresponding corner; length-is the distance from the apertural margin (at the midline if measurement possible) to the apex; face width - is the distance between the corners that border a face; transverse ribs density-is the number of ribs per $5 \mathrm{~mm}$; node density - is the number of nodes per $1 \mathrm{~mm}$ on the ribs; longitudinal bar density - is the number of nodes per $1 \mathrm{~mm}$ on the ribs; ratio of the face width-at the apertural margin to the length of the specimen; and ratio of the shortest to the longest cross-section diameter.

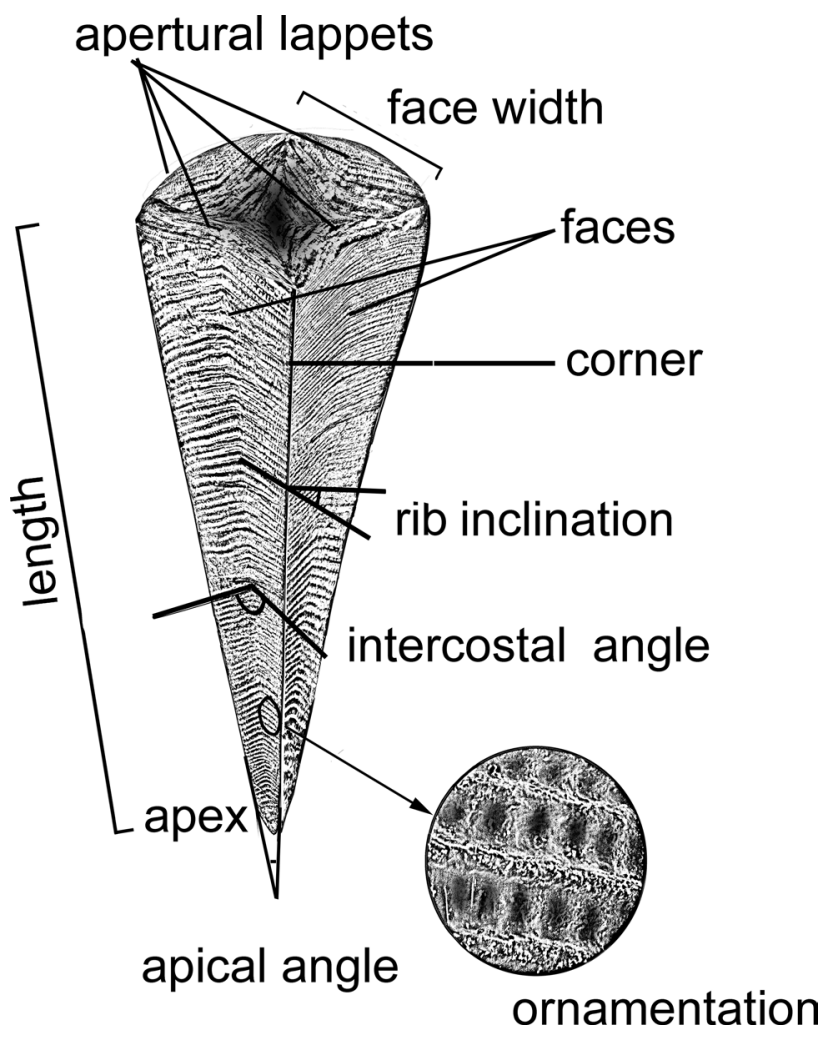

Fig. 5 Schematic drawing of the conulariid described with main morphological elements (after Sendino, 2006) 
The studied specimen in this article is different from any other conulariid species described in the literature. Not only are the biometric measurements different (not useful for erecting new taxa, see Simões et al. 2003), but it is also different morphologically and anatomically (see remarks and comparisons below). Due to the fact that (1) there is only one specimen and (2) it was found in an erratic, it is left under open nomenclature.

The specimen was studied at various angles under incident natural illumination with the naked eye and was also examined with a binocular microscope. Finally, it was studied under scanning electron microscope (SEM) FEI Quanta 650 FEG in low vacuum conditions at the NHM, London. It was photographed with a Canon 5Drs camera mounting $100 \mathrm{~mm}$ and Sigma 50-mm lens and the images were processed using Adobe Photoshop CS6. It was measured directly from photographs.

\section{Systematic palaeontology}

Phylum Cnidaria Verrill, 1866

Class Scyphozoa Götte, 1887

Order Conulariida Miller and Gurley, 1896

Family Conulariidae Walcott, 1886

Genus Conularia Miller in Sowerby, 1820 amended Moore and Harrington, 1956

Observations. Although the date in which Verrill named the phylum Cnidaria was on 29th February 1865, in a communication, it was published in 1866 , in a section of the Communications read before the Essex Institute, in Salem.

The genus Conularia was created by J.S. Miller [formerly Müller] in a manuscript in 1818 to which Sowerby referred in 1821 using plates issued in 1820 . We have checked a copy of The mineral conchology of Great Britain kept at the Natural History Museum, London, in the Sectional Mollusca Library (Earth Sciences Department) with information of when the plates were published.

\section{Conularia aff. cancellata Sandberger, 1847}

Figures 6, 7

non 1820 Conularia quadrisulcata Miller-Sowerby: pl. 260: fig. 4.

non 1824 Conularia quadrisulcata Sowerby-Dalman: 374, pl. 4, fig. 3a-d.

non 1825 Conularia Sowerbii Defrance-de Blainville: 378, pl. 14, fig. 2b-e. (=C. quadrisulcata Sowerby, 1820: pl. 260, figs. 3-6).

non 1837 Conularia quadrisulcata Sowerby-Hisinger: 30, pl. 10, figs. 5a, b.

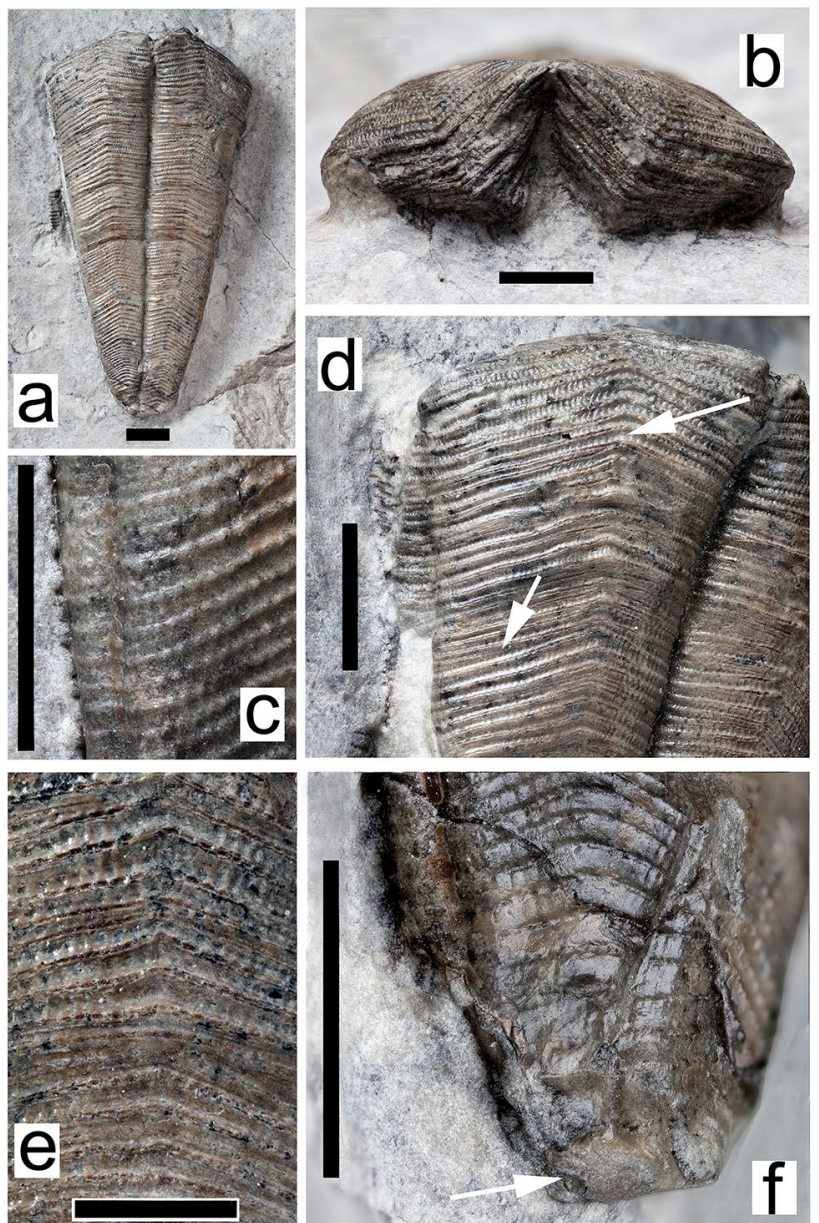

Fig. 6 Conularia aff. cancellata from Macrourus Limestone of Brandenburg. a View of the specimen, with two faces not embedded in the matrix. b Aperture with two lappets seen. c Detail of the ornamentation at the corner sulcus. d Upper part of a face and its apertural margin. e Transverse ribs crossing the midline. $\mathbf{f}$ Apical region with more spaced transverse ribs. Scale bar $5 \mathrm{~mm}$
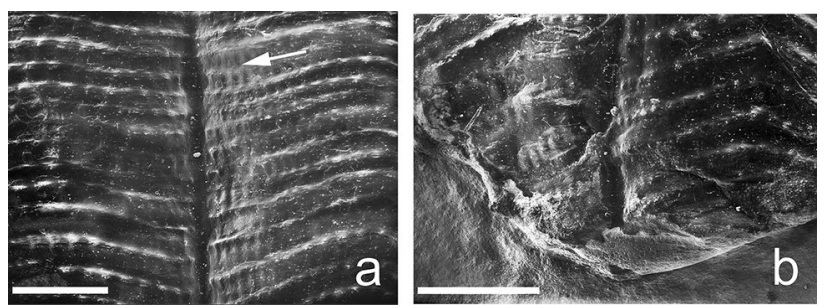

Fig. 7 SEM images of Conularia aff. cancellata from Macrourus Limestone of Brandenburg. a Corner sulcus. b Apical region. Scale bar $2 \mathrm{~mm}$

aff. 1839 Conularia quadrisulcata Sowerby-Murchison: 626-627, pl. 12, fig. 22-22a.

non 1845 Conularia Sowerbii Defrance-Verneuil: 348, pl. 24, figs. 5a, b. 
aff. 1847 Conularia cancellata-Sandberger: 20-21, pl. 1, fig. 11a-c. $(=$ C. quadrisulcata Sowerby in Murchison, 1839).

non 1855 Conularia cancellata Sandberger-McCoy: 287-288.

non 1855 Conularia Sowerbyi Defrance-McCoy: appendix, 6 ,

non 1884 Conularia cancellata-Lindström: 42-44, pl. 1, figs. 1-3.

non 1893 Conularia cancellata Sandberger-Holm: 140-143, pl. 4, figs. 21-25, pl. 6, figs. 29-31.

non 1907 Conularia sowerbyi Verneuil-Slater: 37-39, pl. 5, figs. 7-11.

Material. Specimen number is NHMUK PI CL 1325, kept at the NHM.

Stratigraphic and geographic range. From Macrourus Limestone, Upper Ordovician of Baltoscandia, probable origin in Öland (Sweden), found close to Cottbus, in Spree-Neisse district in southeastern Brandenburg, NE Germany.

Description. Specimen almost completely preserved in three dimensions, measuring about 13-mm wide at the facial margin and 43-mm long, with a slightly smaller ratio than 1:3. Elliptical transverse cross-section (Figs. 6b, 8) with the shortest diameter (semi-minor axis) measured at the aperture margin is $14.5 \mathrm{~mm}$ and the largest diameter (semi-major axis) $23.5 \mathrm{~mm}$, approximately a ratio of 3:5. Aperture with plicated closure with lappets extending inward from corners (Figs. 6b, 8). It is not completely closed. Transverse ribs are not parallel to the lappet sides (Fig. 8). Apical part finishes in less than $2 \mathrm{~mm}$ incomplete apex width (Fig. 6f). Apical angle uniform of $12^{\circ}$ until the last few millimetres at the apical part with $16^{\circ}$. Convex faces, more evident close to the apertural margin (Fig. 6d). Sulcate broad corners that

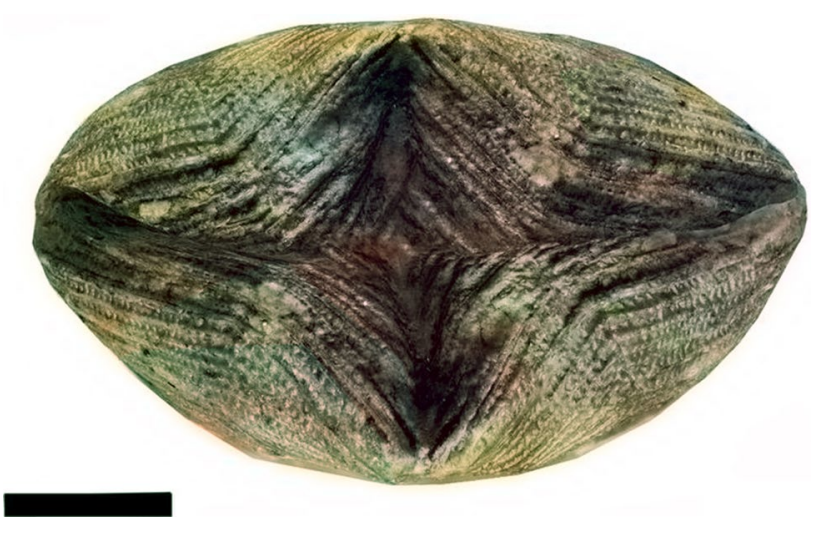

Fig. 8 Reconstruction of the aperture, with a mirror image of half of the aperture, has elliptical cross-section. Seen from above. Scale bar $5 \mathrm{~mm}$ are rounded at the edges and the bottom side, without rib interruption. Those corners corresponding to the semi-minor axis are deeper than the semi-major axis corners. It is possible to see a probable carina-like structure (Fig. 6f with an arrow) related to a shallow corner or that of the semimajor axis. Ornamentation with transverse ribs adaperturally arched that cross the face surface without interruption, in some areas of the test without nodes have the appearance of chains, in other areas ribs with subtle nodes that connect longitudinal bars running through the intercostal spaces (Figs. 6e, 7a) as a grid. The midline does not coincide with the geometrical longitudinal centre of the face, being closer to the adjacent corner that corresponds with the semi-minor axis of the elliptical cross-section, almost to 1:3 of the face width. Facial midline marked by the transverse rib inflection in arc (Fig. 6a, d, e). Intercostal angle varies from top $138^{\circ}-145^{\circ}$, medium part $138^{\circ}-150^{\circ}$, apically $144^{\circ}$ and the lowest preserved adapical part $142^{\circ}$. Angle more obtuse in the middle part of the test, producing transverse bands. Rib inclination varies from $15^{\circ}$ to $22^{\circ}$. It seems to have a pattern to a lower angle towards the apex. Rib density slightly varies from aperture to apical part, from 10 units per $5 \mathrm{~mm}$ close to the aperture, 12 units per $5 \mathrm{~mm}$ at the middle part and 11 units per $5 \mathrm{~mm}$ apically. Adapically, the ribs are thinner, and they optically seem to be more distant, thickening on the apertural side. Ribs bear subtle nodes, if seen, whose density is uniform from the aperture to the apical part, with 4-5 units per $1 \mathrm{~mm}$. These nodes are normally connected through longitudinal bars running across intercostal spaces (Fig. 7a, b). These longitudinal bars have a mainly conical appearance. There are some regions close to the semi-minor axis corner with the midline where longitudinal bars extend from nodes of a transverse rib to gaps of the next adapically transverse ribs (Fig. 7a with an arrow). The density of the nodes and longitudinal bars is very uniform along the test. Density of the longitudinal bars is the same as node density. Intercostal space width varies from $2 / 3$ to 4 times (at specific areas almost 6 times) the rib width. There are few ribs that diverge in two when they approach to the corner or at the midline (Fig. 6d with arrows).

Observations. As the plicated aperture of the specimen object of this paper is not completely closed, this could be explained as (1) at the moment of the death of the organism the aperture was not completely closed or (2) it was not possible to close the aperture probably because of the heavy thickness of the theca and apertural ends (Sendino et al. 2011; Ford et al. 2016). Very few conulariids preserve the aperture (clear examples with photographs by Kutscher and Kümmerle 1964; Sendino et al. 2011; Ford et al. 2016) and we report an aperture almost closed whose lappets do not meet each other and allow seeing, for the first time, most of the internal part of the closure with rib continuation inwards, 
in agreement with Mergl et al. (2016). As is shown in Fig. 8, the lappets and their bending have the same ornamentation as the rest of the test. According to Ford et al. (2016), inward folding depends on wall thickness. This would explain why the lappets of the studied specimen are not completely closed (Fig. 8). The incipient folding indicates some flexibility (Mergl et al. 2016) that started with the midline of the apertural ends folding inwards.

The fact that the transverse bands present in $C$. aff. cancellata are limited by ribs with almost straight course because of the wrinkling affecting the thecae means that those areas have a weaker test, consistent with possible growth resting or slow rate periods. We can distinguish several stages in its growth: first stage with transverse ribs easily seen and protruding longitudinal bars and second stage with wider transverse ribs, narrower intercostal spaces and longitudinal bars more prominent.

Remarks. 'Conularia' cancellata. was erected to avoid a nomenclature issue with two species names (C. quadrisulcata and C. sowerbii) (see Fig. 9). Sandberger (1847) used this name to describe Wenlock specimens, with almost elliptical cross-section, convex faces, longitudinal bars that connect transverse ribs (as in the studied specimen here), mostly coinciding longitudinal bars of consecutive intercostal furrows (like a grid) and slight intercostal angle $\left(130^{\circ}\right)$; however, midline faintly indented, marked by normally meeting transverse ribs in a clear angle and not arched (opposite to our species), sulcate corners with ribs alternating, larger apical angle $\left(20^{\circ}\right)$ and smaller crosssection diameter ratio (1:2). Sandberger (1847) only drew a schematic sketch but made reference to the figure published by Murchison (1839) of ' $C$. quadrisulcata' from the Silurian. In this last cited publication, Murchison observed that Silurian and Carboniferous forms that have been described under ' $C$. quadrisulcata' cannot be the same species, noticing differences in their ornamentation, such as the presence or absence of the intercostal grooves (and longitudinal bars), assigning the presence of this anatomical character to the Silurian form (confirming the best described specimen by Sowerby 1821 - text of this year-of the genotype).

Then, Verneuil (1845) referred to the Silurian form as 'C. sowerbii' (giving authorship to Defrance-unpublished manuscript referred to by de Blainville 1825-) with longitudinal intercostal bars oblique to the transverse ribs for the Silurian form and left " $C$.' quadrisulcata as the Carboniferous form. Then, Sandberger (1847) created ' $C$.' cancellata to avoid being misled by nomenclature and species names with doubtful authorship, giving a more descriptive name that was followed by McCoy (1855), but not by Salter (1855) in the appendix of the same publication where both contributed. Much later Slater (1907) was misled for this last publication, using $C$. 'sowerbyi' for the English Silurian forms to discern them from the Baltic forms (see below), this time describing the aperture with gently rounded triangular lappets and other slight differences (apical angle $10^{\circ}-12^{\circ}$, node and rib density 12 in $5 \mathrm{~mm}$ and 4 in $1 \mathrm{~mm}$, respectively, continuous ribs at the sulcate corners) that approach Slater's description of the erratic studied specimen.

But the $C$. cancellata name was also given to Late Ordovician and Silurian Baltic forms with the typical cancellata/grid appearance that Holm (1893) described in a group without any phylogenetic meaning. Holm (1893) based his description on Lindström (1884), who described C. cancellata from the Silurian of Gotland (Sweden) with lobate lappets, wrinkled test (thin), sulcate midlines not at the midline symmetry longitudinal plane that cuts a face in two equal parts (no taxonomic value). Salter (1866), followed by Kiderlen (1937) and Bouček (1939), explained that as the segmental 'midline' is not in the middle of a face, this would
Fig. 9 Diagram showing some of the synonyms of Conularia quadrisulcata with the authors and year they were published. NB the author is not always the species author

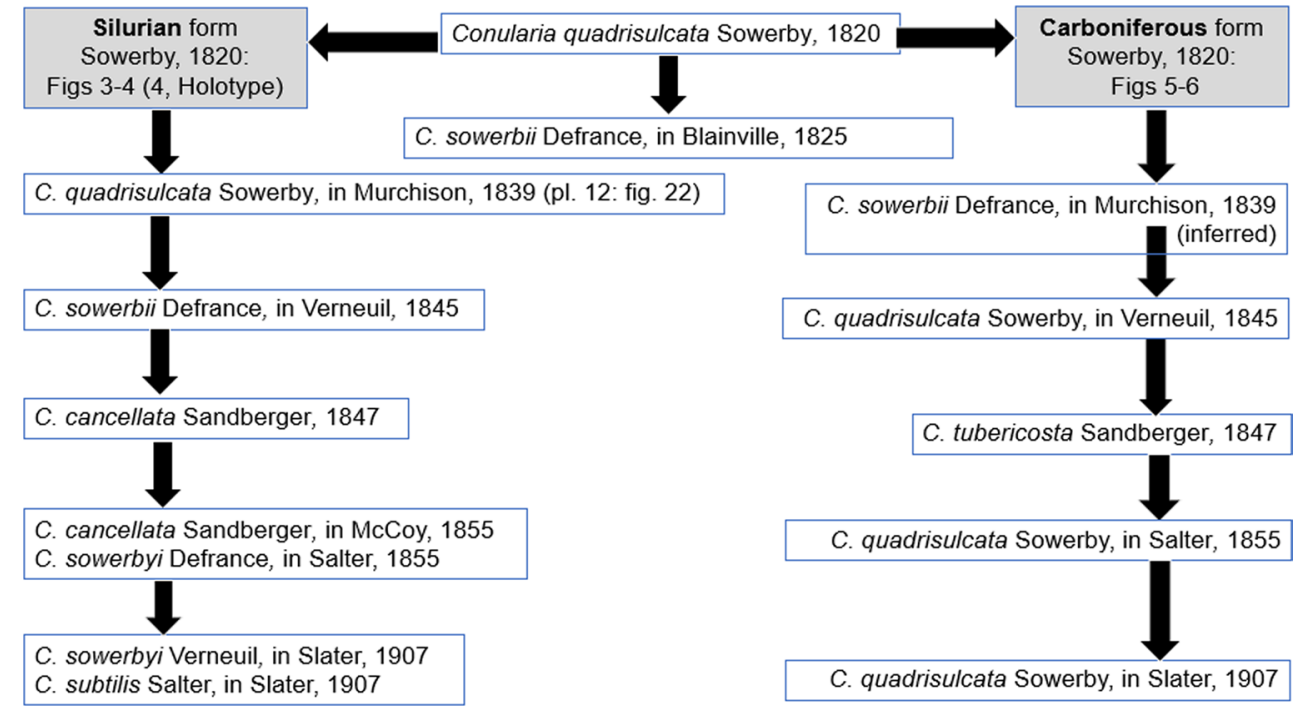


imply that the original theca cross-section would have been rhomboidal or elliptical, and would not have been a consequence of taphonomic processes. Although this is true, conulariid asymmetry at the midline has been demonstrated a non-specific morphological element (Sendino et al. 2012) that can occur intraspecifically. It is speculated that the signalling proteins and genes are involved in controlling the asymmetries, although the trigger is not known. Lindström (1884) also noticed that spines from the middle of the test, which become more prominent distally, are arranged in alternating positions in the intercostal spaces whose width is twice that of the transverse rib width. In the studied species, this intercostal space width is variable from the proximal to the distal part. This species was also claimed to be in Macrourus Limestone erratics of Eberswalde area (Brandenburg, Germany) by Remelé (1885).

As we have noted, this species has been described with different morphological and anatomical characters and its name has been used as a dustbin for cancellata-grid forms found in the literature, from the Late Ordovician to Devonian from Avalonia, Baltica, Laurentia and Gondwana.

Comparison. In a general view, $C$. aff. cancellata resembles ' $C$.' orthoceratophila (Fig. 10). Both of them are from Baltic Late Ordovician erratics, the latter also found from erratics of Öland. ' $C$.' orthoceratophila was figured, but not described, by Roemer (1876) using only one specimen. This species differs from $C$. aff. cancellata in rhomboidal cross-section (Fig. 10b), having transverse ribs meeting in opposed positions at the midline and being interrupted and intertwined at corners (Fig. 10c, e), with homogeneous intercostal space width (Fig. 10d, f) and lack of nodes on the transverse ribs. Later, Holm (1893) made a description of 'C. orthoceratophila' on a Baltic specimen that does not correspond with the specimen from the Late Ordovician erratics of Sorau figured by Roemer (1876). Holm's (1893) specimens have square cross-section, larger apical angle $\left(22^{\circ}\right)$, less obtuse intercostal angle $\left(130^{\circ}\right)$, minor transverse rib density ( 5 units per $5 \mathrm{~mm}$ ) and also minor node and longitudinal bar density (less than 3 units per $1 \mathrm{~mm}$ ) and continuous transverse ribs at sulcate corners and midline. It is unquestionable that the fact Roemer (1876) did not describe the species and that Holm did not access the holotype caused Holm (1893) to misinterpret Roemer's (1876) figure. Another author who referred to ' $C$.' orthoceratophila is Koken (1896), who gave slightly different rib density to the holotype (14 units per $5 \mathrm{~mm}$ ) and also described the rhomboidal cross-section. Kiderlen (1937) and Bouček (1939) wrote that the aperture closure of ' $C$.' orthoceratophila has lobate lappets, but there is nothing written on where they obtained the information or which specimens were studied as the holotype does not preserve the aperture, only an incipient apertural end (Fig. 10b).

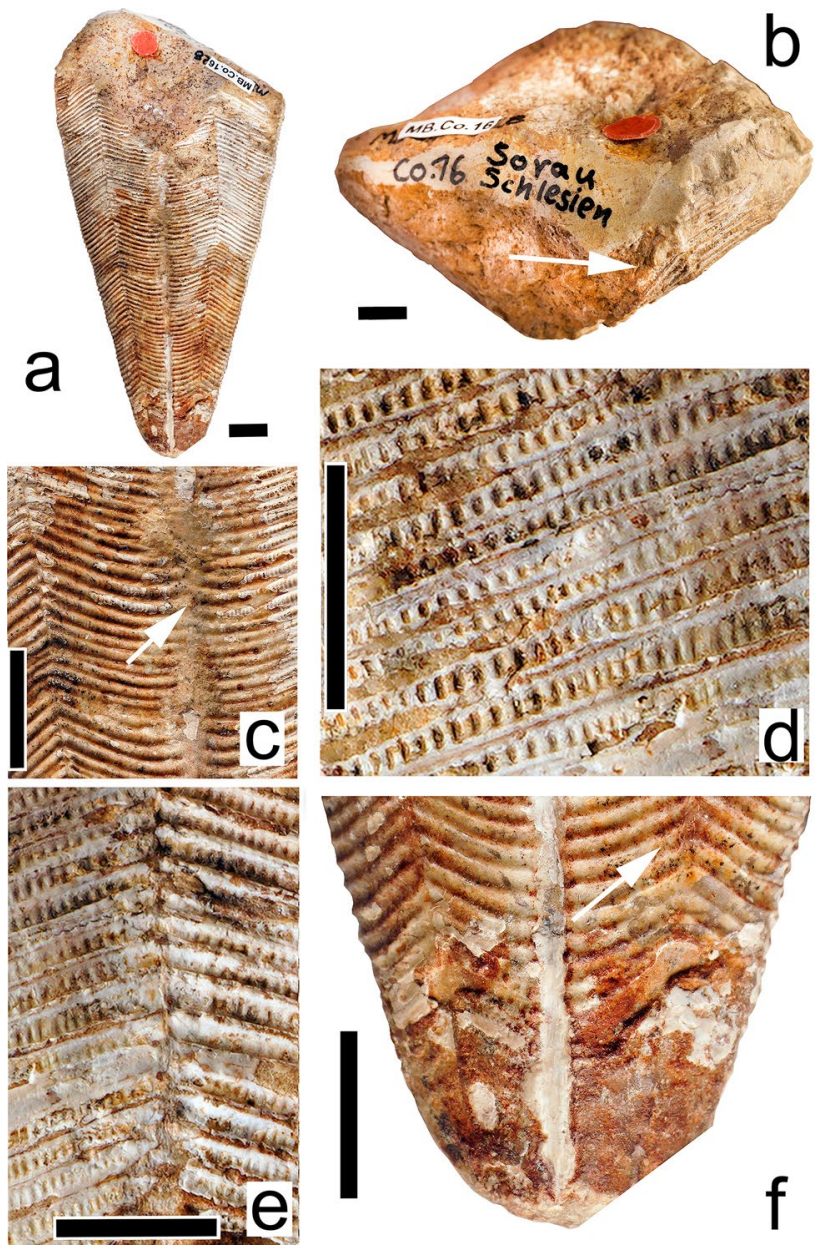

Fig. 10 Holotype of Paraconularia orthoceratophila (MB Co16, Museum für Naturkunde Berlin) from Macrourus Limestone of Sorau. a General view of the specimen. b Fragment of an incipient apertural end (with a white arrow) and rhomboidal cross-section. c Detail of the ornamentation at the corner sulcus with intertwined transverse ribs (with white arrow). d Detail of the longitudinal intercostal bars. e Transverse ribs meeting at the midline. f Apical region with acute intercostal angle (white arrow). Scale bar $5 \mathrm{~mm}$

Other Ordovician Baltic species that have some resemblance are C. oelandica, C. telum and C. pectinata. All of them are included in the Cancellatae group defined by Holm (1893) and have been found in erratics of Öland. C. oelandica is only found in Macrourus Limestone erratics, without proper longitudinal intercostal bars connecting the nodes, more pronounced nodes and a more obtuse intercostal angle than the studied species, but the transverse ribs may have a chain appearance as in the studied specimen. ' $C$.' telum, only from the Cystoidean Limestone (Ludibundus limestone), has rhomboidal cross-section, transverse ribs normally alternating at the midline and interrupting at the sulcate corners, more acute apical angle, and lower transverse rib and longitudinal intercostal bar densities. C. pectinata is from Cystoidean and Macrourus limestones. This last species 
also has rhomboidal to lenticular (rounded extremes) crosssection and also midline not at the symmetric longitudinal face plane, more obtuse intercostal angle, around twice the longitudinal intercostal bar density. Holm (1893) recognised a younger form (Late Ordovician) with the longitudinal bar density higher than the oldest form.

It would be recommendable to make a phylogenetic analysis of the Ordovician Baltic conulariid species to confirm if the existence of longitudinal intercostal bars is a homoplasic character, possibly shared with the Silurian forms of Avalonia.

\section{Preservation}

The test has several marks (circular and subcircular, Fig. 11 with arrows), probably produced by epibionts. These marks are approximately at the same level on both visible faces in the distal zone. On one of these marks, it is possible to see how the ornamentation has been affected by the marks. This could be explained if the conulariid was able to modify its sculpture whilst alive. There are some reasons why the epibionts could have attached to the conulariid: (1) they would avoid being smothered in the muddy bottom (later siltstones); (2) they could avoid predators that were on the seabed or lower tiers; (3) they would have had access to more oxygenated waters; and (4) they could also benefit from the currents that the conulariid would produce for their feeding; in the event that both organisms were filter feeders, the epibionts could take advantage of the surplus that the conulariid could not take. It is not the first time that conulariids have been reported with marks of other organisms attached to their thecae (see Van Iten et al. 2018 and biographical references there). There is another mark (highlighted area in Fig. 11) without ornamentation and smooth surface. This implies the animal was attacked in life and was able to heal the theca.

Both organisms, conulariid and epibionts, lived in shallow warm waters when, probably during a storm-like episode, as a defence the conulariid theca closed its aperture, or it was at the moment of closure, that the theca was uprooted and toppled, starting the biostratinomic processes. Most of its surface would sink into the mud (at least $3 / 4$ of its length) which would preserve its sculpture. The raised part would be affected minimally by mechanical destruction, as the organism was dead; there is lack of healing (Fig. 11, close to the circular marks) in the area without outermost lamella of the test, possibly due to marine currents (Fig. 11) affecting one of the sides more than the other.

The test thickness that has facilitated its preservation may represent an adaption to an environment of moderately high physical energy and an increase of predators. The fact that the conulariid is of medium size would imply that the force exerted by currents would affect them more than smaller conulariids (Allen 1982; Jerre 1994a, b), keeping them out of the highest energy waters. Conularia aff. cancellata occur in siltstone that represents moderate high energy. Hence, the thickness of the theca may have helped them to survive in those waters.

It was in the Ordovician when the Baltoscandian epicontinental sea covered the east and southeast of the Scandinavian Caledonides, in a mud mound environment with moderately

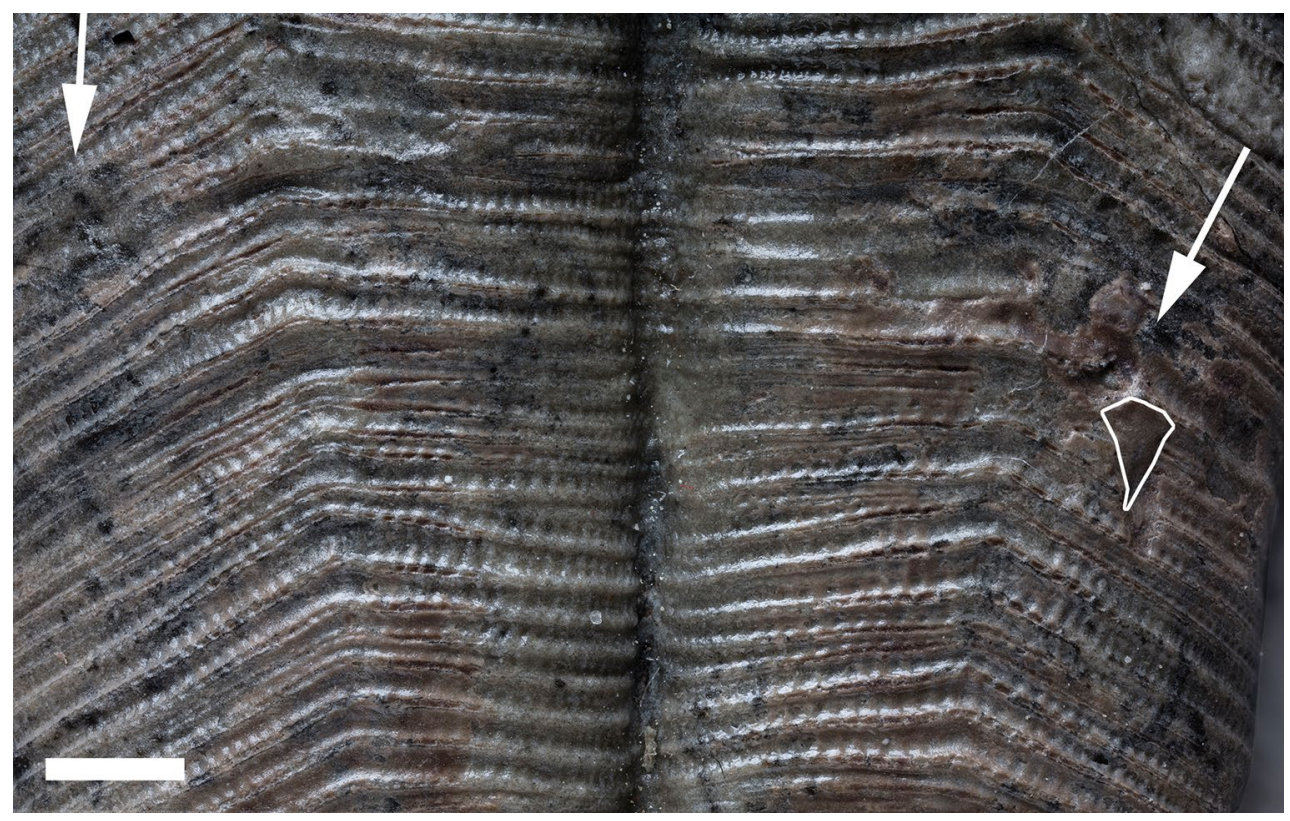

Fig. 11 Circular and subcircular marks (white arrows) produced by epibionts. Marked area with healing surface. Scale bar $2 \mathrm{~mm}$ 
agitated waters, that during an episode of high energy, the theca was buried rapidly in the mud and later settled out as currents diminished giving way to diagenesis. This allowed it to have exceptional preservation.

\section{Conclusion}

A conulariid form from the Late Ordovician erratics of Brandenburg is described with a plicated closure allowing us to see, for first time, most of the internal part of the closure with rib continuation inwards. This form has cancellata ornamentation typical of Baltic species but differs from those already described. As there is only one specimen, it has been named under open nomenclature. The detail of its exceptional preservation in the Baltoscandian epicontinental sea may imply a swift burial after an episode of relatively high energy in warm waters. This paper contributes to a better understanding of conulariid morphology and also of the erratics from the Northern European Lowlands. The good preservation of the fauna in the present study underlines the importance of erratic boulders in taxonomic studies, as well as revealing recent events in the history of the earth and enhancing the biostratigraphic knowledge of Baltoscandia.

Acknowledgements We acknowledge Richard Fortey (NHM) for helping with trilobite identification; Kevin Web and Lucie Goodayle, both NHM science photographers, for the specimen macro-images; Olev Vinn (University of Tartu) for accessing Estonian bibliographical references and revising the manuscript; Graham Young (University of Manitoba) and Mike Reich (SNSB-Bayerische Staatssammlung für Paläontologie und Geologie München) for improving the manuscript; Aurelio J. Patierno (British Library) as science reference specialist for assistance with citations; and Andreas Abele (Museum für Naturkunde Berlin) for Paraconularia orthoceratophila images.

Funding This research received no specific grant from any funding agency in the public, commercial, or not-for-profit sectors.

Open Access This article is licensed under a Creative Commons Attribution 4.0 International License, which permits use, sharing, adaptation, distribution and reproduction in any medium or format, as long as you give appropriate credit to the original author(s) and the source, provide a link to the Creative Commons licence, and indicate if changes were made. The images or other third party material in this article are included in the article's Creative Commons licence, unless indicated otherwise in a credit line to the material. If material is not included in the article's Creative Commons licence and your intended use is not permitted by statutory regulation or exceeds the permitted use, you will need to obtain permission directly from the copyright holder. To view a copy of this licence, visit http://creativecommons.org/licenses/by/4.0/.

\section{References}

Andersson, J.G. 1893. Ueber Blöcke aus dem jüngeren Untersilur auf der Insel Öland vorkommend. Öfversigt af Kongliga VetenskapsAkademiens Förhandlingar 8: 521-540.
Barrande, J. 1857. Parallèle entre les dépôts Siluriens de Bohème et de Scandinavie. Abhandlungen der Königlichen Böhmischen Gesellschaft der Wissenschaften [V] 9: 1-67.

Barrande, J. 1867. Systeme Silurien du Centre de la Boheme. 1ere. Partie Recherches Paleontologiques, Classe des Mollusques. Ordre des Pteropodes 3(1): i-xv + 1-54 + 140-161. Paris.

Bartholomäus, W.A., and E. Böhmecke. 2007. Perforate Peridermalskulptur bei einer Conularie (Ordoviz). Archiv für Geschiebekunde 4: 659-671.

Bassler, R.S. 1911. The Early Paleozoic Bryozoa of the Baltic Provinces. Smithonian Institution United States National Museum Bulletin 77: 1-348.

Bergström, S.M. 2007. The Ordovician conodont biostratigraphy in the Siljan region. In WOGOGOB 2007. Field guide and Abstracts, eds. J.O.R. Ebbestad, L.M. Wickstrom, and A.E.S. Högstrom. Sveriges geologiska undersökning, Rapporter och Meddelande 128: $26-41$.

Bergström, S.M., and P. Ahlberg. 2004. Guide to some classical Ordovician and Cambrian localities in the Fågelsång area, Scania, southern Sweden. In International Symposium on Early Palaeozoic Palaeogeography and Palaeoclimate, eds. A. Munnecke, T. Servais. Erlanger geologische Abhandlungen, Sonderband 5: 81-90.

Bekker, H. 1924. Mõned uued andmed Kukruse lademe stratigraafiast ja faunast [Stratigraphical and paleontological supplements on the Kukruse stage of the Ordovician Rocks of Eesti (Estonia)]. Geoloogia-Instituudi Toimetused Publications of the Geological Institution 1: 1-19.

Blainville, H.M.D. de. 1825. Manuel de malacologie et de conchyliologie, 2 vols., 1-664. Paris: Levrault.

Bohlin, B. 1949. The Asaphus Limestone in Northernmost Öland. Bulletin of the Geological Institution of the University of Upsala 33: 529-570.

Boll, E. 1857. Beitrag zur Kenntnis der silurischen Cephalopoden im nord-deutschen Diluvium und den angrenzenden Lagern Schwedens. Archiv des Vereins der Freunde der Naturgeschichte in Mecklenburg 11: 58-95.

Boll, E. 1859. Petrefactologische Kleinigkeiten. Archiv des Vereins der Freunde der Naturgeschichte in Mecklenburg 13: 160-171.

Boulton, G.S., T.G.D. Smith, A.S. Jones, and J. Newsome. 1985. Glacial geology and glaciology of the last mid-latitude ice sheets. Journal of the Geological Society 142: 447-474.

Böse, M. 1990. Reconstruction of ice flow directions south of the Baltic Sea during the Saalian and Weichselian glaciations. Boreas 19: 217-226.

Böse, M., and M. Górska. 1995. Lithostratigraphical studies in the outcrop at Ujście, Torún-Eberswalde Pradolina, western Poland. Eiszeitalter und Gegenwart 45: 1-14.

Bouček, B. 1939. Conularida. In Handbuch der Palaozoologie 2A, ed. O.H. Schindewolf, A113-A131. Berlin: Gebrüder Borntraeger.

Brood, K. 1979. Conulariids. In Lower Wenlock faunal and floral dynamics - Vattenfallet Section, Gotland, eds. V. Jaanusson, S. Laufeld, and R. Skoglund. Sveriges Geologiska Undersökning (C: Avhandlingar och uppsatser) 762: 183-184.

Cepek, A.G., D. Hellwig, L. Lippstreu, H. Lohde, H. Ziermann, and R. Zwirner. 1975. Zum Stand der Gliederung des Saale-Komplexes im mittleren Teil der DDR. Zeitschrift für geologische Wissenschaften 3: 1049-1075.

Dalman, J.W. 1824. Några Petrificater, fundne i Östergötlands öfvergångskälk, aftecknade och beskrifne. Kongliga vetenskapsakademiens handlingar (Series 3) 5: 368-377.

Delle, N. 1937. Zemgales līdzenuma, Augšzemes un Lietuvas devona nogulumi [Devonian deposits of the Zemgale lowland, Augšzemes and Lithuania]. Latvijas Universitātes raksti [Acta Universitatis Latviensis], Matêmatikas un dabas zinâtṇu fakultâtes Serija 2 1937: 106-384. (in Latvian). 
Dzik, J. 1984. Phylogeny of the Nautiloidea. Palaeontologia Polonica 45: 1-219.

Eichwald, E. von. 1860. Lethaea Rossica ou Paléontologie de la Russie. Premier Volume, Ancienne Période, 1-1657. Stuttgart: E. Schweizerbart.

Ehlers, J., L. Eißmann, L. Lippstreu, H.-J. Stephan, and S. Wansa. 2004. Pleistocene glaciations of North Germany. In Quaternary Glaciations-Extent and Chronology, Part I: Europe, eds. J. Ehlers and P.L. Gibbard, 135-146. Amsterdam: Elsevier.

Erlingsson, U. 1994. The 'Captured Ice Shelf' Hypothesis and Its Applicability to the Weichselian Glaciation. Geografiska Annaler (A: Physical Geography) 76: 1-12.

Flodén, T. 1980. Seismic stratigraphy and bedrock geology of the central Baltic. Stockholm Contributions in Geology 35: 1-240.

Ford, R.C., H. Van Iten, and G.R. Clark. 2016. Microstructure and composition of the periderm of conulariids. Journal of Paleontology 90: 389-399.

Gottsche, C. 1877. Die Sedimentär-Geschiebe der Provinz SchleswigHolstein, 1-65. Yokohama: Lévy \& Salabelle.

Hacht, E. von, and H.J. von Hacht. 1974. Sylt: Lavendelblauer ordovizisch-silurischer Hornstein, Pfenniggerölle aus der Kreide. Der Geschiebesammler 8: 19-28.

Hacht, U. von, ed. 1985. Fossilien von Sylt, 1-131. Hamburg: IngeMaria von Hacht.

Hacht, U. von. 1990. Seltene Fossilien von Sylt. In Fossilien von Sylt III, ed. U. von Hacht, 93-103. Hamburg: Inge-Maria von Hacht.

Hadding, A. 1958. The Pre-Quaternary Sedimentary Rocks of Sweden. VII: Cambrian and Ordovician Limestones. Lunds Universitets Arsskrift (N.F. Avd 2) 54: 7-262.

Haacke, P. 2016. Semi-automated mapping of geomorphological features in the Baruth Ice-Marginal Valley using LiDAR-data. Applying isolation, segmentation and automatisation to LiDARdata via object-based image analysis (OBIA), 1-24. Unpublished BSc Earth Sciences Thesis, Universiteit van Amsterdam.

Hannemann, M., and E. Schlegel. 1965. Untersuchungen zur stratigraphischen Einstufung von Geschiebemergeln aus Ostbrandenburg. Berichte der geologischen Gesellschaft der DDR 10: 773-790.

Haupt, K. 1878. Die Fauna des Graptolithengesteines. Neues Lausitzer Magazin 54: 29-113.

Heidenhain, F. 1869. Ueber Graptolithen führende DiluvialGeschiebe der norddeutschen Ebene. Zeitschrift der Deutschen Geologischen Gesellschaft 21: 143-182.

Hergarten, B. 1988. Conularien in Deutschland. Der Aufschluss 39: 321-356.

Hisinger, W. 1837. Lethaea Svecica seu Petrificata Sveciae, iconibus et characteribus illustrata, 1-124. Norstedt: Holmiae.

Holm, G. 1893. Sveriges Kambrisk-Siluriska Hyolithidae och Conulariidae. Sveriges Geologiska Undersökning (C: Afhandlingar och uppsatser) 112: 1-172.

Hucke, K., and E. Voigt. 1967. Einführung in die Geschiebeforschung (Sedimentärgeschiebe), 1-132. Oldenzaal: Nederlandse Geologische Vereniging.

Jaanusson, V. 1960. The Viruan (Middle Ordovician) of Öland. Bulletin of the Geological Institution of the University of Upsala 38: 207-288.

Jaanusson, V. 1982. Introduction to the Ordovician of Sweden. In Fieldexcursion guide, IV International Symposium on the OrdovicianSystem, eds. D.L. Bruton, and S.H. Williams. Paleontological Contributions from the University of Oslo 279: 1-9.

Jentzsch, A. 1880. Übersicht der silurischen Geschiebe Ost- und Westpreussens. Zeitschrift der Deutschen Geologischen Gesellschaft 32: 623-630.

Jerre, F. 1993. Conulariid microfossils from the Silurian Lower Visby Beds of Gotland, Sweden. Paleontology 36: 403-424.
Jerre, F. 1994a. Taxonomy and functional morphology of Silurian conulariids from Gotland. Lunds Publications in Geology 117: $1-33$.

Jerre, F. 1994b. Anatomy and phylogenetic significance of Eoconularia loculata, a conulariid from the Silurian of Gotland. Lethaia 27: 97-109.

Karsten, G. 1869. Die Versteinerungen des Uebergangsgebirges in den Geröllen der Herzogthümer Schleswig und Holstein, 1-85. Kiel: E. Homann.

Kiderlen, H. 1937. Die Conularien. Über Bau und Leben der ersten Scyphozoa. Neues Jahrbuch für Mineralogie etc. (B: Geologie und Palaontologie) 77: 113-169.

Klöden, K.F. 1834. Die Versteinerungen der Mark Brandenburg, insonderheit diejenigen, welche sich in den Rollsteinen und Blöcken der Südbaltischen Ebene finden, 1-378. Berlin: G. Lüderitz.

Koken, E. 1896. Die Leitfossilien. Ein Handbuch für den Unterricht und für das Bestimmen von Versteinerungen, 1-848. Leipzig: C.H. Tauchnitz.

Krause, A. 1877. Die Fauna der sogen. Beyrichien- oder ChonetenKalke des norddeutschen Diluviums. Zeitschrift der deutschen geologischen Gesellschaft 29: 1-49.

Krause, A. 1891. Beitrag zur Kenntnis der Ostrakoden-Fauna in silurischen Diluvialgeschieben. Zeitschrift der deutschen geologischen Gesellschaft 43: 488-521.

Kröger, B. 2004. Revision of Middle Ordovician orthoceratacean nautiloids from Baltoscandia. Acta Palaeontologica Polonica 49: $57-74$.

Kröger, B., L. Hints, and O. Lehnert. 2017. Ordovician reef and mound evolution: the Baltoscandian picture. Geological Magazine 154: 683-706.

Kutscher, F., and E. Kümmerle. 1964. Beiträge zur Sedimentation und Fossilführung des Hunsrückschiefers. Die Conularien-Arten des Hunsrückschiefers. Notizblatt des Hessischen Landesamtes für Bodenforschung zu Wiesbaden 92: 52-59.

Leuchtenberg, M.E.N.H. 1843. Beschreibung einiger neuer Thierreste der Urwelt aus den silurischen Kalkschichten von Zarskoje-Selo, 1-26. St. Petersburg

Lindström, G. 1867. Nomina fossilium siluriensum Gotlandiae, 1-8. Stockholm.

Lindström, G. 1882. Anteckningar om silurlagren på Carlsoarne. Öfversigt af Kongl. Vetenskaps-akademiens forhandlingar 3: 5-30.

Lindström, G. 1884. On the Silurian Gastropoda and Pteropoda of Gotland. Kungliga Svenska Vetenskaps-Akademiens Handlingar 19: $1-250$.

Lüttig, G. 1991. Erratic boulder statistics as a stratigraphic aid. Examples from Schleswig-Holstein. Newsletters on Stratigraphy 25: 61-74.

Malinky, J.M. 2007. Hyolitha from the Early Paleozoic glacial erratic boulders (Geschiebe) of Germany and Poland. Fossil Record 10: 71-90.

Maletz, J., and H. Schöning. 2017. Graptolites from glacial erratics of the Laerheide area, northern Germany. PalZ. Paläontologische Zeitschrift 91: 223-235.

Männil, R., 1959. Problems of stratigraphy and bryozoans from the Ordovician of Estonia, 1-542. Sciences Thesis. Tallinn: Institute of Geology, Academy of Sciences ESSR. (in Russian).

Martna, J. 1955. Studies on the Macrourus and Slandrom Formations I Shell Fragment Frequencies of the Macrourus Formation and Adjacent Strata at Fjäcka. Gräsgård, and File Haidar. Geologiska Föreningen i Stockholm Förhandlingar 77: 229-256.

McCoy, F. 1855. Lower Palaeozoic Mollusca. In A synopsis of the classification of the British Palaeozoic rocks, with a systematic description of the British Palaeozoic fossils, eds. A. Sedgwick, F. McCoy, and J.W. Salter, 1-661. London: Parker \& Son. 
McNamara, K.J. 1980. Taxonomy and distribution of chasmopine trilobites. Geological Magazine 117: 65-80.

Mergl, M., L. Ferrová, and J. Frýda. 2016. Armoured test of Early Devonian Mesoconularia (Conulariida) from the Prague Basin (Czech Republic): probable adaptation to increased predation pressure. Bulletin of Geosciences 91: 561-581.

Mierzejewski, P. 2003. Autothecal morphs and dormancy in the camaroid graptolite Xenotheka. Acta Palaeontologica Polonica 48: 93-98.

Miller, S.A., and W.F.E. Gurley. 1896. New species of Palaeozoic invertebrates from Illinois and other states. Bulletin of the Illinois State Museum of Natural History 11: 1-50.

Moore, R.C., and H.J. Harrington. 1956. Conulata. In Treatise on Invertebrate Paleontology, Coelenterata F, ed. R.C. Moore, F54-F66. New York, N.Y.: Geological Society of America and Lawrence, Kans.: University of Kansas Press.

Murchison, R.I. 1839. The Silurian system, founded on geological researches in the counties of Salop, Hereford, Radnor, Montgomery, Caermarthen, Brecon, Pembroke, Monmouth, Gloucester, Worcester, and Stafford: with descriptions of the coalfields and overlying formations. Part 2, 579-768. London: John Murray.

Neben, W., and H.H. Krueger. 1971. Fossilien ordovizischer Geschiebe. Staringia 1: 1-5.

Neben, W., and H.H. Krueger. 1973. Fossilien ordovicischer und silurischer Geschiebe. Staringia 2: 1-10.

Neben, W., and H.H. Krueger. 1979. Fossilien kambrischer, ordovizischer und silurischer Geschiebe. Staringia 5: 1-63.

Noetling, F. 1882. Ueber Lituites lituus. Zeitschrift der Deutschen Geologischen Gesellschaft 34: 156-193.

Patrunky, H. 1928. Pteropoden, Gastropoden und Brachiopoden aus Geschieben der silurischen Orthocerenkalke (Schlüssel-Auszug). Zeitschrift für Geschiebeforschung 4: 127-137.

Raab, T., A. Raab, A. Nicolay, M. Takla, F. Hirsch, H. Rösler, and A. Bauriegel. 2016. Opencast mines in South Brandenburg (Germany) - archives of Late Quaternary landscape development and human-induced land use changes. Archaeological and Anthropological Sciences 8: 453-466.

Remelé, A. 1880. Ueber einige neue oder seltene Versteinerungen aus silurischen Diluvialgeschieben der Gegend von Eberswalde. In Festschrift für die Fünfzigjährige Jubelfeier der Forstakademie Eberswalde, 179-252. Berlin: J. Springer.

Remelé, A. 1883. Untersuchungen über die versteinerungsführenden Diluvialgeschiebe des norddeutschen Flachlandes mit besonderer Berücksichtigung der Mark Brandenburg. 1. Stück Allgemeine Einleitung nebst Uebersicht der älteren baltischen Sedimentgebilde, Untersilurische Cephalopoden, 1-108. Berlin: Springer.

Remelé, A. 1885. Katalog der von Prof. Dr. Ad. Remelé beim internationalen Geologen-Congress zu Berlin in September und October 1885 ausgestellten Geschiebesammlung, 1-32. Berlin: A.W. Schade.

Roemer, F. 1876. Lethaea Geognostica, oder Beschreibung und Abbildung der für die Gebirgs-Formationen bezeichnendsten Versteinerungen, Theil I: Lethaea Palaeozoica, Volume 1, Atlas. Stuttgart: J.C. Henzler.

Roemer, F. 1885. Lethaea erratica oder Aufzählung und Beschreibung der in der norddeutschen Ebene vorkommenden DiluvialGeschiebe nordischer Sedimentär-Gesteine. Palaeontologische Abhandlungen 2: 250-420.

Rudolph, F. 1997. Geschiebefossilien Teil 1: Paläozoikum. Fossilien, Sonderheft 12: 1-65.

Salter, J.W. 1855. Appendix A. In A synopsis of the classification of the British Palaeozoic rocks, with a systematic description of the British Palaeozoic fossils, A. Sedgwick, F. McCoy, and J.W. Salter, 1-661. London: Parker \& Son.
Salter, J.W. 1866. Appendix. On the fossils of North Wales. In The geology of North Wales, ed. Ramsay. Memoirs of the Geological Survey of Great Britain, and of the Museum of Practical Geology in London 3: 239-381.

Sandberger, G. 1847. Die Flossenfüsser oder Pteropoda der ersten Erdbildungs-Epoche. Conularia und Coleoprion. Neues Jahrbuch für Mineralogie, Geognosie, Geologie und Petrefaktenkunde 1847: $8-25$.

Schallreuter, R. 1994. Conularia sp. aus Grauem Orthocerenkalk. Geschiebekunde aktuell 10: 69-70.

Schlotheim, E.F. von 1820. Die Petrefactenkunde auf ihrem jetzigen Standpunkte durch die Beschreibung seiner Sammlung versteinerter und fossiler Überreste des Tier- und Pflanzenreichs der Vorwelt erläutert, 1-437. Gotha.

Schuijf, P. 1960. Conularia cancellata Sandberger in een Groningse zwerfsteen. Grondboor en Hamer 5: 127-132.

Schulz, W. 2003. Geologischer Führer für den norddeutschen Geschiebesammler, 1-508. Schwerin: cw Verlagsgruppe.

Sendino, M.C. 2006. Estudio morfológico de los Conulariida (Cnidaria). Pliocénica 5: 1-16.

Sendino, C. 2009. Revisión de la colección de Conulariidae de The Natural History Museum de Londres (Reino Unido), 1-601. Madrid: Universidad Complutense de Madrid. http://eprints.ucm. es/8237/1/T30640bis.pdf

Sendino, C., K. Zágorsek, and Z. Vyhlasová. 2011. The aperture and its closure in the Ordovician conulariid. Acta Palaeontologica Polonica 56: 659-663.

Sendino, C., K. Zágorsek, and P.D. Taylor. 2012. Asymmetry in an Ordovician conulariid cnidarian. Lethaia 45: 423-431.

Simões, M.G., S.C. Rodrigues, J.M. Leme, and H. Van Iten. 2003. Some middle Paleozoic conulariids (Cnidaria) as possible examples of taphonomic artifacts. Journal of Taphonomy 1: 165-186.

Sjögren, A. 1852. Anteckningar om Öland, ett bidrag till Sveriges geologi. Öfversigt af Kongl. Vetenskaps-akademiens forhandlingar 8: 36-42.

Slater, I. 1907. A Monograph of British Conulariae. Monograph of the Palaeontographical Society 6: 1-41.

Sowerby, J. 1818-1821. The mineral conchology of Great Britain; or coloured figures and descriptions of those remains of testaceous animals or shells, which have been preserved at various times, and depths in the earth, 3, 1-194, pls. 204-306. (1818: pls. 204-221; 1819: pls. 222-253; 1820: pls. 254-271; 1821: pls. 272-306). London: W. Arding Company.

Stasińska, A. 1967. Tabulata from Norway, Sweden and from the erratic boulders of Poland. Palaeontologica Polonica 18: 1-112.

Steusloff, A. 1892. Sedimentärgeschiebe von Neubrandenburg. Archiv des Vereins der Freunde der Naturgeschichte in Mecklenburg 45: 161-179.

Stouge, S. 2004. Ordovician siliciclastics and carbonates of Öland, Sweden. In International Symposium on Early Palaeozoic Palaeogeography and Palaeoclimate, eds. A. Munnecke, T. Servais. Erlanger geologische Abhandlungen, Sonderband 5: 91-111.

Striegler, R. 1992. Zugänge zur geologischen Sammlung des Niederlausitzer Museums der Natur und Umwelt in den Jahren 1984 bis 1991. Natur und Landschaft in der Niederlausitz 13: 100-118.

Törnquist, S.L. 1883. Öfversigt öfver bergbyggnaden inom siljansområdet Dalarna. Sveriges Geologiska Undersökning C 57: 1-59.

Van Iten, H., J.C. Gutiérrez-Marco, L.A. Muir, M.G. Simões and J.M. Leme. 2018. Ordovician conulariids (Scyphozoa) from the Upper Tiouririne Formation (Katian), eastern Anti-Atlas Mountains, southern Morocco. In The Great Ordovician Biodiversification Event: Insights from the Tafilalt Biota, Morocco, eds. A.W. Hunter, J.J. Álvaro, B. Lefebvre, P. Van Roy, and S. Zamora. Geological Society, London, Special Publications 485. https:// doi.org/10.1144/SP485.5 
Verneuil, A.E. 1845. Mollusques Ptéropodes. In Géologie de la Russie d'Europe des Montagnes de l'Oural, vol. 2, ed. R.I. Murchison, E. de Verneuil, and A. de Keyserling, 1-504. London: J. Murray.

Verrill, A.E. 1866. Classification of Polyps: (Extract condensed from a Synopsis of the Polypi of the North Pacific Exploring Expedition, under Captains Ringgold and Rogers, U.S.N.) Part I, 29th Feb 1865. Communications read before the Essex Institute, Proceedings of the Essex Institute 4 (years 1864-5): 145-152. https:// archive.org/details/proceedingsofess04esse/page/144/mode/2up/ search/cnidaria.

Vinn, O., and M.A. Wilson. 2015. Symbiotic interactions in the Ordovician of Baltica. Palaeogeography, Palaeoclimatology, Palaeoecology 436: 58-63.

Vinn, O., A. Ernst, M.A. Wilson and U. Toom, U. 2019. Symbiosis of conulariids with trepostome bryozoans in the Upper Ordovician of Estonia (Baltica). Palaeogeography, Palaeoclimatology, Palaeoecology 518: 89-96.

Walch, J.E.I. 1771. Die Naturgeschichte der Versteinerungen zur Erläuterung der Knorrischen Sammlung von Merkwürdigkeiten der
Natur. Dritter Theil. In Die Naturgeschichte der Versteinerungen, 5 vols., J.E.I. Walch, 1-235. Nürnberg: Felßecker.

Walcott, C.D. 1886. Second contribution to the studies on the Cambrian Faunas of North America. Bulletin of the United States Geological Survey 30: 731-1095.

Wickström, L.M. 2007 Ordovician of the Storsjön Area. In WOGOGOB 2007. Field guide and Abstracts, eds. J.O.R. Ebbestad, L.M. Wickstrom, and A.E.S. Högstrom. Sveriges geologiska undersökning, Rapporter och Meddelande 128: 41-44.

Wiman, C. 1895. Paleontologische Notizen 1-2. Conularia loculata n. sp. Bulletin of the Geological Institution of the University of Upsala 2(3): 113-117.

Wiman, C. 1905. Paläontologische Notizen 3-6, 3. Über Robergia microphthalmus Lns. und Triarthrus jemtlandicus Lns. Bulletin of the Geological Institutions of the University of Upsala 6: $77-84$.

Wiman, C. 1908. Studien über das Nordbaltische Silurgebiet. Bulletin of the Geological Institution of the University of Upsala 8: 73-168. 